\title{
Representing Authentic Learning Designs Supporting the Development of Online Communities of Learners
}

\author{
Ron Oliver \\ Edith Cowan University, AUSTRALIA \\ r.oliver@ecu.edu.au \\ Jan Herrington \\ The University of Wollongong, AUSTRALIA \\ jan_herrington@uow.edu.au
}

\author{
Anthony Herrington \\ The University of Wollongong, AUSTRALIA \\ tony_herrington@uow.edu.au \\ Thomas C Reeves \\ The University of Georgia, USA \\ treeves@uga.edu
}

\begin{abstract}
Authentic learning designs have been explored for some time now and have frequently been shown to provide learning settings that provide many meaningful contexts for learning. These meaningful contexts provide not only encouragement for students to learn but also a raft of learning enhancements including higher-order learning and forms of learning support. The establishment of a sense of community among learners creates support mechanisms that can readily enhance learning outcomes. This paper describes several technology-facilitated authentic learning designs that involve the development and support of learning communities. The learning designs are represented in several forms to provide an overview of the various elements in the learning setting and to indicate the learning and teaching strategies associated with the community development and support. The paper illustrates the different purposes learning design representations can serve and argues the need for further research, in particular, designbased research, to develop standard forms of representations that can be widely used to provide descriptions that support discovery and reuse.
\end{abstract}

Keywords

authentic learning, learning designs, higher education, professional learning, vocational education.

\section{Introduction}

More and more, students in online learning settings are taking ownership of their learning and being encouraged to work collaboratively with their peers and others as an integral part of the learning experience. The advantages and opportunities that stem from communities of learners and collaborative learning activities have long been recognised as important, and shown to provide considerable learning opportunities.

However, a recent research study by Liu, Magjuka, Bonk, and Lee (2007) examined the question 'does sense of community matter?' within the context of online courses. Interviews with faculty members involved in an online MBA program indicated that online instructors 'have a weak awareness of online community and low value of its learning impact' (p. 9). Another recent study by Zhang and Walls (2006) investigated the degree to which online instructors value and implement Chickering and Gamson's (1987) well-known Seven Principles for Good Practice in Undergraduate Education. The seven principles are: encourage student-faculty contact, encourage cooperation among students, encourage active learning, give prompt feedback, emphasize time on task, communicate high expectations, and respect diverse talents and ways of learning. Survey 
results from 49 online instructors indicated that the least highly endorsed principle was encouraging cooperation among students. These two studies suggest that many academic staff teaching online are either unaware of the benefits of online communities of learners or do not appreciate the potential of such virtual communities for enhancing learning.

Meanwhile, other studies indicate that the steadily growing numbers of students enrolled in online courses are increasingly being encouraged to work collaboratively with their peers and others as an integral part of the online learning experience (Gabriel, 2004; Roberts, 2004; Swan \& Shea, 2005; Goodsell, Maher, \& Tinto, 1992; Slavin, 1990). Learning can be enhanced through the dialogue and discussion that is involved and the collaboration itself can help to generate learning communities that offer many tangible forms of support for the learners (Slavin, Hurley \& Chamberlain, 2003; Ewing, 1999).

There are many ways for teachers to create opportunities for learner online interactivity and collaboration that can lead to the development of learning communities. Clearly the form and scope of the collaboration and interaction will have considerable impact on the learning opportunities and outcomes that result. Learning activities that typically involve collaboration among learners exist in such environments as problem-based learning and project-based learning (Bonk, 1998). Often teachers will create opportunities for collaboration through group-based tasks and activities. For effective learning communities to be derived from student interactions, teachers really need to design their learning settings around activities based on deliberate learning designs that have been shown to be able to deliver these learning outcomes. Authentic learning is one such form of learning design.

This paper describes the learning designs for a number of different authentic online learning settings, each of which involves deliberate collaboration and interactions that are intended to lead to the development of effective learning communities among the participants. The paper provides representations of several such activities through learning designs which reveal the critical underpinning tasks, supports and resources and the roles of the various stakeholders in the learning process. Two discrete forms of representation are used to showcase each authentic learning setting. The paper concludes with a discussion of the scope and form of representations that are needed to support teachers seeking to implement authentic learning activities in their own context.

\section{Collaborative learning}

Collaborative learning designs and their attendant learner interactions can take many different forms. Whenever students work together as part of a learning activity, some form of group work can be observed. Typically group work can be defined across a continuum which describes activities ranging from cooperation through to collaboration. Cooperation describes students working alongside each other in the same learning space for mutual benefit, but ostensibly with reasonable degrees of independence. Collaboration on the other end of the continuum describes interactions that are interdependent and actually promote the kinds of joint contributions of students that enable outcomes to exceed what might normally be achieved by individual activity.

Collaborative learning takes place when the following conditions are met: students have a common goal, share responsibilities, are mutually dependent and need to reach agreement through open interaction (Dolmans, Wolfhagen, \& Scherpbier, 2003). Forms of groupwork include students working in groups on class work and learning tasks, students contributing ideas and sharing knowledge on public bulletin boards and students working in groups on projects. Successful group work generally requires students to demonstrate skills in collaboration, and not simply cooperation in the division of roles and responsibilities (Slavin, 1990). Collaboration provides many opportunities to enhance learning. For example, it enhances efficiency with respect to knowledge generation and problem solving. It makes time on task more productive in that groups are able to accomplish more than individuals. It brings multiple perspectives to bear on problems thereby enhancing student knowledge and understanding. Well-designed collaborative learning activities capture the dynamic of real world complexity. In such settings students need to develop 
and share alternative views. Students learn to be able to articulate their own understandings and ideas and to develop and refine these based on interactions with others. Learning is enhanced when students are able to view problems and solutions from multiple perspectives that may challenge their own assumptions or poorly conceived ideas.

Unfortunately, research focused on the learning outcomes achieved from collaborative and cooperative activities — compared to individual learning — often fail to show any significant gains, at least with respect to the outcomes measured by traditional assessments (cf., Yazici, 2005). Some students show a greater preference for group work than others and in order for collaborative activities to achieve their intended outcomes, teachers often need to stimulate interactions among students. Many students need to be encouraged and guided to develop appropriate climates within groups for sharing and interaction (Wubbells \& Levy, 1993).

A number of instructional strategies have been found to provide stronger support for collaborative learning. These include the provision of guidance in group processes (Lizzio \& Wilson, 2005) and support for such activities as self-management, conflict resolution, decision-making, and equitable participation (Yazici, 2005). It is less efficient and problematic to allow these skills to develop by themselves rather than through some proactive teaching or intervention.

Research into the concept of community can provide a strong conceptual basis and understanding of the group dynamics associated with successful group work and learner collaboration. Recent work in the area of learning communities provides useful guidance about instructional strategies associated with effective collaborative learning, especially within online learning settings.

\section{Learning communities}

When learners collaborate meaningfully in authentic learning settings, the outcomes from the collaboration provide mutual benefits. These benefits can be manifold and can be shown to assist in the construction of knowledge (Jonassen, 2000), to provide scaffolding and support structures for the learners (Vygotsky, 1978) and to promote and encourage learners' engagement in the learning process (Hiltz, 1998). The term learning community is often used to describe a learning space where participants are encouraged to collaborate and communicate. When the participants in a learning space are able to develop of a sense of community, many significant learning advantages and opportunities can result (Putnam, 2000). Learning communities provide support for individual learners and help to encourage active participation. They also help to ensure the efficient and equitable functioning of the group and encourage a focus on the learning activity instead of a focus on group dynamics and group management.

McMillan and Chavis (1996) suggest that there are four important elements associated with the formation of a sense of community within collaborative groups. These include a feeling of belonging to a group (membership), a feeling of influence within the group, fulfilment of needs and a shared emotional connection with other members. These elements are present at varying levels in different community settings, although shared emotional connection is considered the definitive element of true community (McMillan, 1996).

Achieving these elements in a learning space requires considerable skill and expertise on the part of the teacher. In face-to-face classrooms where students enjoy frequent opportunities to interact in many different ways throughout their learning experiences, the formation of learning communities are common. Effective teachers are usually able to foster quite strong communities that provide many supports for individual learners from other members within the group. Often there will be several communities within a single classroom setting. Even in settings where teachers apply no particular strategy, students will often end up supporting each other in varying ways as a consequence of their own social skills and forming supportive learning communities. Indeed, if no formal structures exist in learning environments to facilitate collaboration, students will often seek such opportunities covertly (Herrington \& Oliver, 2000) 
Although learning communities can be established online, there are often particular difficulties and impediments for learners seeking to collaborate in online settings. These are typically associated with learners' physical separation and the restricted means which online environments provide for learners' communication and interaction.

\section{Supporting online learning communities}

In recent years there has been considerable interest in exploring instructional strategies that can support the development of learning communities in online settings. Paloff and Pratt (2005) distinguish between an online community, where people meet with a common interest, and an online learning community where people engage in collaborative learning and the reflective practice involved in transformative learning. Online learning communities provide many opportunities to enhance and support learning in online settings. In investigating the development and sustainment of learning communities in online settings, Brook and Oliver (2003) proposed a number of factors as influencing community outcomes in the Learning Community Development Model (LCDM) (Figure 1).

In developing the LCDM, Brook and Oliver (2003) identified a number of factors that impact on students' learning experiences and which influence students' development of a sense of community in online learning settings. Many of the factors were found to be inherent in the distributed learning setting itself and outside the realm of the teacher and the students. Impediments were found to exist in system factors, for example, difficulties with communications and technologies to support interaction. Learning contexts such as the size of online cohorts, the learning designs employed and students' prior experience in online settings also were found to play a part in the development of learning communities.

The research revealed that the critical factors influencing the development of learning communities in online settings were to be found in the processes employed by the teachers teaching the courses. Of critical importance in the delivery of the learning was the learning design that was used to create the learning environment and to guide the selection of the learning activities. Successful learning designs for developing learning communities were those where there were meaningful contexts created for the collaborative activities, and where the learning environment was based on activities that enabled and supported communication but also provided moderating and facilitation for the communication and interaction.

Figure 1: The Learning Community Development Model (Brook \& Oliver, 2003)

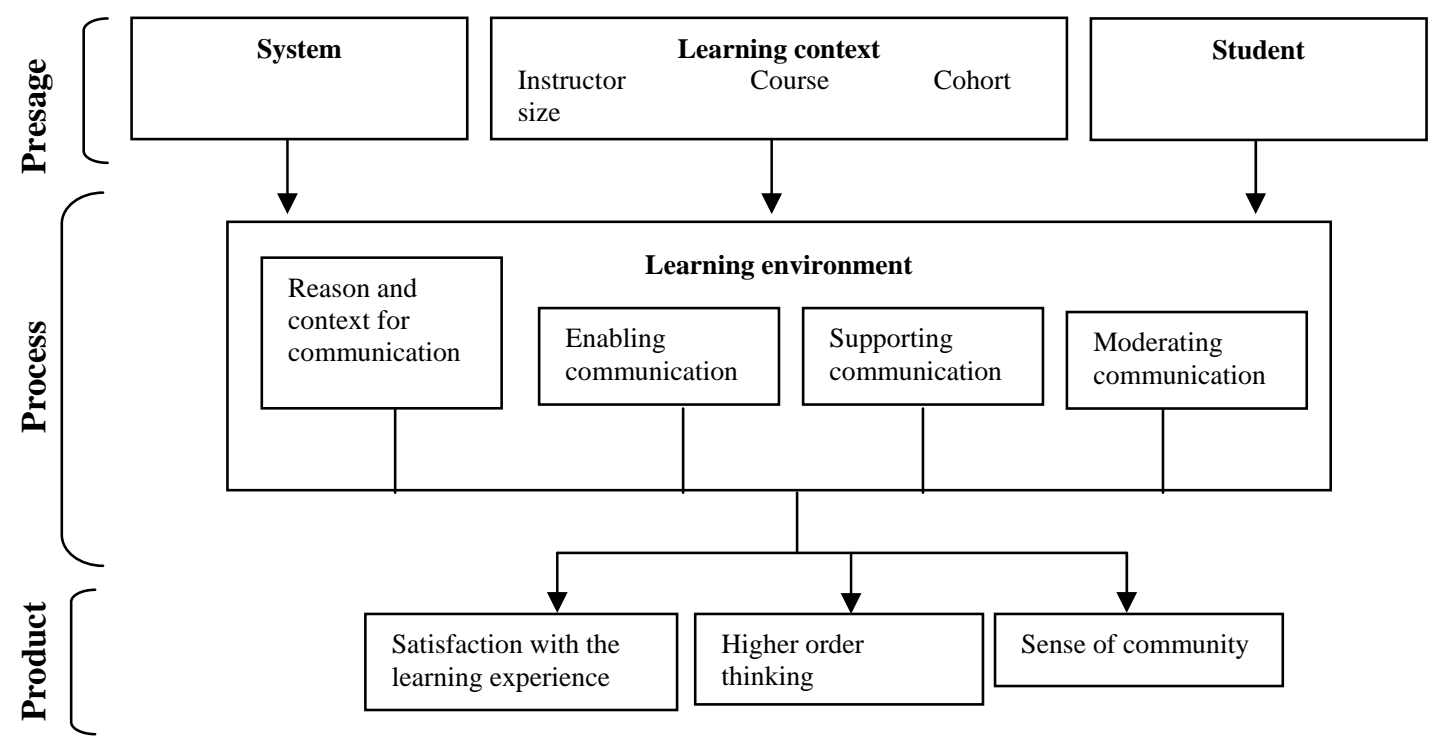


There are potentially a large number of learning designs that can provide contexts and support for online learning involving learning communities. These include such forms as problem-based learning and project-based learning. Our previous research has identified and demonstrated that strong collaborative and group-based learning contexts exist in online authentic learning settings and that successful learning in these settings often draws from their capacity to develop and support learning communities.

\section{Authentic activities}

In 1993, Brown and Duguid noted that the characteristics of such situated and authentic learning environments had never been fully explored. They wrote: 'One of the most persistent educational questions following discussions of situated learning has been: How can these situated theories be operationalized?' (1993, p. 10). In our research, we have previously identified the critical characteristics of the learning tasks or activities that are needed to create and support the contexts, appropriate and necessary for an authentic learning setting. The characteristics have been drawn from a wide review of recent research and contemporary learning theories. In reflecting on the characteristics of learning tasks described by researchers, ten broad design characteristics of authentic activities have been identified (cf., Herrington, Reeves, Oliver, \& Woo, 2004):

- Authentic activities require real-world relevance: Activities match as nearly as possible the real-world tasks of professionals in practice rather than decontextualised or classroom-based tasks (e.g., Brown, Collins \& Duguid, 1989).

- $\quad$ Authentic activities are ill-defined, requiring students to define the tasks and sub-tasks needed to complete the activity: Problems inherent in the activities are ill-defined and open to multiple interpretations rather than easily solved by the application of existing algorithms. In such situations, learners must identify their own unique tasks and sub-tasks in order to complete the major task (e.g., Cognition and Technology Group at Vanderbilt, 1990).

- $\quad$ Authentic activities comprise complex tasks to be investigated by students over a sustained period of time: Activities are completed in days, weeks, and months rather than minutes or hours. They require significant investment of time and intellectual resources (e.g., Bransford et al., 1990).

- Authentic activities provide opportunities for students to examine the task from different perspectives, using a variety of resources: The task affords learners the opportunity to examine the problem from a variety of theoretical and practical perspectives, rather than allowing a single perspective that learners must imitate to be successful. The use of a variety of resources rather than a limited number of preselected references requires students to detect relevant from irrelevant information (e.g., Young, 1993).

- Authentic activities provide the opportunity to collaborate: Collaboration is integral to the task, both within the course and the real world, rather than achievable by an individual learner (e.g., Lebow \& Wager, 1994).

- Authentic activities provide the opportunity to reflect: Activities need to enable learners to make choices and reflect on their learning both individually and socially (e.g., Gordon, 1998).

- $\quad$ Authentic activities can be integrated and applied across different subject areas and lead beyond domain-specific outcomes: Activities encourage interdisciplinary perspectives and enable students to play diverse roles thus building robust expertise rather than knowledge limited to a single well-defined field or domain (e.g., Jonassen, 1991).

- $\quad$ Authentic activities are seamlessly integrated with assessment: Assessment of activities is seamlessly integrated with the major task in a manner that reflects real world assessment, 
rather than separate artificial assessment removed from the nature of the task (e.g., Herrington \& Herrington, 1998).

- $\quad$ Authentic activities create polished products valuable in their own right rather than as preparation for something else: Activities culminate in the creation of a whole product rather than an exercise or sub-step in preparation for something else (e.g., Barab Squire \& Dueber, 2000).

- Authentic activities allow competing solutions and diversity of outcome: Activities allow a range and diversity of outcomes open to multiple solutions of an original nature, rather than a single correct response obtained by the application of rules and procedures (e.g., Duchastel, 1997).

There are many ways to operationalise these characteristics into particular learning environments and the quality of the authentic learning experience for students will depend very much on the extent to which each of these characteristics can be achieved. The critical element in an authentic learning setting is the complex task that is chosen to form the basis of the learner activity. The form and nature of the task will vary considerably between authentic learning activities depending on the learning outcomes being sought. Despite the intuitive appeal of authentic learning environments, and the evidence that they are effective in promoting higher order learning, these learning environments can appear difficult to many teachers seeking to implement alternative approaches in their teaching. Often teachers will recognise the opportunities and advantages of an alternative teaching approach but are discouraged by the difficulties associated with the implementation (Blake, 2000). The solution to the promotion and support of authentic learning settings appears to lie in their accessibility and visibility, two factors strongly influenced by the availability of appropriate representations of such learning settings.

\section{Representations of authentic learning settings}

The following section describes and discusses the learning designs of a number of authentic learning activities that have been applied in online settings which have involved the establishment of learning communities. The activities have been chosen to reflect a range of settings and contexts to demonstrate the strategies that have been employed to provide the context for the community development and also to provide a guide for teachers seeking to implement such a learning design themselves in the form of a road map and lesson plan. The development of learning designs, roadmaps describing the roles, responsibilities and activities of the stakeholders in learning settings, provide some means to facilitate teacher use of alternative learning approaches (Beetham, 2004).

There have been a number of projects that have sought to provide representations of authentic learning settings to facilitate their sharing and reuse by other teachers. The Information and Communication Technologies and Their Role in Flexible Learning Project (AUTC, 2003) developed representations of a number of examples using a temporal sequence format (Oliver, Harper, Hedberg, Wills \& Agostinho, 2002). This representation provides an effective means for demonstrating the critical elements in learning activities for the purpose of providing teachers with an understanding of the learning processes involved but is less effective in providing the forms of information teachers will need to actually implement the approach. Falconer at al. (2007) use the terms inspirational designs and runnable designs to distinguish between such forms. Inspirational designs are those whose purpose is to facilitate an understanding of the various elements within a learning activity as a means to encourage their adoption while runnable designs provide the information a teacher would need to carry out the actual implementation. There are quite strong differences in the information each type of design needs to carry.

As mentioned previously, authentic learning settings depend strongly on the nature of the tasks that are chosen to underpin the learning activities. In order to support and facilitate effective learning tasks in online settings, learning communities are often used. The creation and support of 
learning communities can require particular strategies and activities on the part of stakeholders and for the inexperienced teacher, there can be many traps and pits to avoid. A runnable learning design, revealing the roles and responsibilities of participants and the sequences of events to follow, would appear to offer the form of information and guidance needed to not only implement the design but to achieve a degree of success in delivering the learning outcomes sought.

The learning designs in the following pages are represented in two forms. The first form uses the temporal sequence approach to provide an overarching view of the learning setting in terms of the tasks, resources and supports, so that the intended learning outcome can be understood. The second representation provides a more detailed description of the activities that the various stakeholders in the learning setting undertake. This representation provides a runnable representation of the learning design (Falconer et al., 2007) that will assist teachers to better know and understand the actual teaching and learning steps as support for their potential reuse and application in other learning settings.

\section{Authentic learning designs involving online learning communities}

\section{Postgraduate course in instructional design (PCID)}

The Postgraduate Course in Instructional Design (PCID) is a course offered at Masters level in higher education. A learning community forms an integral component of the learning environment and plays an important role in supporting the learning. The course in total comprises a 13 week program offered totally online with no face-to-face component. Students in the course are most likely never to have met, but are possibly acquainted with some members of their class through previous online studies.

The course aims to allow participants to examine instructional design in a more contemporary way, encouraging students to explore newer approaches influenced by constructivist philosophies, as well as the more established and traditional systems-based approaches. Students are given three tasks that allow them to explore and create a range of responses to issues associated with instructional design. 
Figure 2: Temporal learning sequence for Postgraduate Course in Instructional Design (PCID)

\begin{tabular}{|c|c|c|c|}
\hline RESOURCES & TASKS & SUPPORTS & \\
\hline $\begin{array}{l}\text { Subject website (includes } \\
\text { exploration of task options } \\
\text { with links to possible } \\
\text { topics; embedded search } \\
\text { engines; links to university } \\
\text { library and digital libraries) }\end{array}$ & $\begin{array}{l}\text { Students explore one of two } \\
\text { reflection tasks: } \\
\text { 1. How do I learn? } \\
\text { 2. How is learning presented in } \\
\text { popular culture? } \\
\text { Students share their reports on the } \\
\text { subject website } \\
\end{array}$ & $\begin{array}{l}\text { Teacher guidance on form and } \\
\text { features of subject website } \\
\text { Teacher and students suggest } \\
\text { topics and examples on online } \\
\text { forum } \\
\text { Teacher and peer support and } \\
\text { feedback }\end{array}$ & 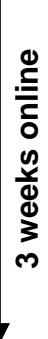 \\
\hline $\begin{array}{l}\text { Subject website (includes a } \\
\text { short list of suggested } \\
\text { readings available as e- } \\
\text { readings; embedded search } \\
\text { engines; links to university } \\
\text { library and digital libraries; } \\
\text { explanation of group space } \\
\text { and tools available) }\end{array}$ & $\begin{array}{l}\text { Teams create product (wiki) on } \\
\text { the history of ID together with } \\
\text { examples of at least } 3 \text { ID models } \\
\text { Students share their wiki products } \\
\text { on the subject website }\end{array}$ & $\begin{array}{c}\text { Within group support on } \\
\text { dedicated forum } \\
\text { Broader teacher and peer support } \\
\text { on general forum } \\
\text { Teacher and peer support and } \\
\text { feedback }\end{array}$ & 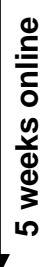 \\
\hline $\begin{array}{l}\text { Subject website (includes } \\
\text { a short list of suggested } \\
\text { readings available as e- } \\
\text { readings; a modelled plan } \\
\text { or approach to the task; } \\
\text { embedded search } \\
\text { engines; links to university } \\
\text { librarv and diaital libraries) }\end{array}$ & $\begin{array}{c}\text { Individuals design a web-based } \\
\text { or face-to-face learning } \\
\text { environment to suit their own } \\
\text { context } \\
\text { Students share website and/or ID } \\
\text { plans on the subject website }\end{array}$ & $\begin{array}{l}\text { Within group support on } \\
\text { dedicated forum } \\
\text { Broader teacher and peer support } \\
\text { on general forum } \\
\text { Teacher and peer support and } \\
\text { feedback }\end{array}$ & 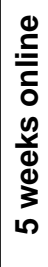 \\
\hline
\end{tabular}

\section{a. Tasks}

The tasks instantiate the elements of authentic activities described earlier, by offering complex, open-ended, task-based learning opportunities. They effectively require the students to reflect on instructional design (through an examination of their own learning, or a representation of learning on film), to synthesis knowledge of instructional design, and to design a learning environment for a context that relates to their own situation. The course relies on the community of its members to share growing understanding of instructional design, and to create products that can be shared and critiqued.

In the first task, students can choose one of two activities. They can undertake to learn a short selfcontained skill or subject that could be completed within 2-3 weeks, such as, how to use the bibliographic referencing tool EndNote. Students observe and reflect as they learn, and then articulate their findings in a paper beginning: 'I learn best by ...'. In the second choice, students can choose a movie or television program that is set in a school/university or incorporates classroom scenes (examples generated by students include School of Rock, Dangerous Minds, Dead Poet's Society, 10 things I Hate About You, Italian for Beginners). They analyse the assumptions the teacher makes about how students learn and how the instruction reflects those assumptions, and summarise the principles of learning reflected in the learning environment in a paper beginning: 'Students learn best by ...'. In this task, they are also required to discuss whether they agree with this approach.

In the second task, students collaboratively create a reference article (a wiki) on the subject of instructional design (not unlike the kind of article that might be published in Wikipedia). They describe what instructional design is and explain a little of its history, with reference to opinions 
and perspectives from experts and teachers. They need to include descriptions of different ID models and explain their principles, and to provide an example of a lesson plan or learning environment that exemplifies each model.

In the third task, students individually design a learning environment using principles of instructional design for their own educational contexts. This task provides an opportunity to perform a real instructional design task and to produce the kind of work that someone might hire a consultant for. If students do not have a context of immediate relevance they are given instructions to produce a wiki entry for teachers and others who want to find out and are encouraged to choose something that (a) people might want to learn, and (b) that is of interest to them. Some examples are: how to research your family tree, how to invest in the stock market, how to make cheese at home, how to make a movie with iMovie, or how to write a children's book or your life story. Students plan the design, development, implementation and evaluation of the learning environment, including the tasks, resources and supports that will be provided.

\section{b. Resources}

There is a recommended textbook for the course that students can download in pdf format from the course website. Few other specific resources have been provided. Those that are given are provided as starting points for discussion rather than a full list of essential readings. There are, however, some powerful tools on the website to assist learners to find resources, such as links to search engines and data bases, including an RSS feed on instructional design from Education Network Australia (edna - an online resource collection and collaborative network). Such an arrangement enables students to share their resource finds and to comment on the usefulness of each resource to each other - something that is unlikely to occur when students are given a finite list of resources. This further assists in the building of learning community.

\section{c. Supports}

Technology provides the facility for human community support to work seamlessly in the online learning environment. In addition to the tools provided throughout the whole course (discussion

forums, email, chats), the second task also necessitates the use of a suite of collaborative tools dedicated to each group. Each group has the use of a webpage that includes embedded tools in the form of: a discussion forum, a chat space, an upload facility and a wiki. At a distance, students can collaboratively create their wiki products, and rely on the ready access to support from each other in their groups, from other groups and from the course facilitator.

\section{d. The learning community}

The learning community that is needed to support learning in the Postgraduate Course in Instructional Design (PCID) relies to a large degree on the relative actions of many stakeholders in the learning setting. The setting needs community to make it work. The students bring their own contexts to the environment, and the discussions and activities appear to relate strongly to their own goals and achievements. Students need to contribute their work to the wikis and to feel comfortable with the feedback and comment it will receive. They need to be willing to express their ideas and to recognise they are valued and appreciated by other learners. Participation in collaborative activities needs to be high from the outset, culminating in the group tasks and publishing of group products and instructional design plans. It is clear that an educational community such as the one described here generally has, by default, in the nature of its assessment items, a significant purpose for all participants (McMillan, 1996).

The roles and responsibilities of the various stakeholders in the completion of Task 2 in the PCID in shown in Table 1. The representation of the learning design uses a strategy which highlights the various roles and their relationship and sequencing. 
Table 1: Stakeholder representation of Task 2 in PCID

\begin{tabular}{|c|c|c|c|c|}
\hline Evaluator & Facilitator & Team & Student & Coordinator \\
\hline & & & & Establishes website \\
\hline \multirow[t]{9}{*}{$\begin{array}{l}\text { Monitors discussion } \\
\text { and feedback and } \\
\text { collects relevant data }\end{array}$} & $\begin{array}{l}\text { Provide general } \\
\text { introduction to task by } \\
\text { email and postings }\end{array}$ & & $\begin{array}{l}\text { Read and become } \\
\text { familiar with the } \\
\text { problem and task }\end{array}$ & \multirow[t]{9}{*}{$\begin{array}{l}\text { Deals with } \\
\text { administrative } \\
\text { requests }\end{array}$} \\
\hline & $\begin{array}{l}\text { Establish group web } \\
\text { pages and } \\
\text { collaboration tools } \\
\text { (discussion forums, } \\
\text { chats, wikis) }\end{array}$ & & & \\
\hline & $\begin{array}{l}\text { Nominate group } \\
\text { compositions and } \\
\text { advise students }\end{array}$ & & & \\
\hline & $\begin{array}{l}\text { Provide assistance on } \\
\text { using group web } \\
\text { spaces }\end{array}$ & & $\begin{array}{l}\text { Initiates contact with } \\
\text { other team members } \\
\text { and uses group forum } \\
\text { to establish } \\
\text { communication }\end{array}$ & \\
\hline & \multirow[t]{4}{*}{$\begin{array}{l}\text { Provide assistance } \\
\text { and comment/ } \\
\text { feedback, } \\
\text { recommended } \\
\text { resources, }\end{array}$} & $\begin{array}{l}\text { Research and } \\
\text { brainstorm ideas } \\
\text { Select ID models }\end{array}$ & \multirow[t]{4}{*}{$\begin{array}{l}\text { Provide } \\
\text { comment/feedback on } \\
\text { general forum }\end{array}$} & \\
\hline & & $\begin{array}{l}\text { Collaboratively } \\
\text { construct wiki }\end{array}$ & & \\
\hline & & Polish and edit wiki & & \\
\hline & & \multirow[t]{2}{*}{ Publish final work } & & \\
\hline & Assesses group work & & & \\
\hline Evaluates task & & & & $\begin{array}{l}\text { Submits group marks } \\
\text { to central record } \\
\text { keeping }\end{array}$ \\
\hline
\end{tabular}

\section{BEST teacher education}

The Beginning and Establishing Successful Teachers (BEST) website

(www.uow.edu.au/educ/students/best.html) was developed and implemented in 2005 as a resource and support network for preservice teachers exiting primary and early childhood teacher education courses at the University of Wollongong to undertake a professional career as a teacher. Although the site was primarily developed for primary and early childhood teachers, it has been further developed for other specialised cohorts, such as high school physical and health education teachers. The site is organised around significant problem-based issues identified by beginning teachers, alongside communication tools that enable social interaction, support and reflection.

The site was designed to build upon the existing relationships between student teachers recognising that difficulties of site identification, establishment and maintenance that can occur when communities of learning are formed 'from scratch', where there is no compelling reason for members to interact Schuck (2003). The site uses the Janison Learning Management System (www.janison.com.au). 


\section{a. Tasks}

Authentic tasks arise from issues surrounding the classroom practices of community members. The issues are categorised around themes previously identified by members and reflect the major areas of concern for beginning teachers: classroom management, teaching and learning, professional responsibilities, special needs, assessment and casual teaching. Tasks are not set in the form of pre-determined topics for discussion, but emerge naturally from the concerns and issues of the community members. The task then is one of 'problem resolution' within the context of interactions, collaborations and responses provided by the participants themselves.

\section{b. Resources}

The site has a number of resources that are useful and timely for beginning teachers:

- $\quad$ FAQs based on problems raised around the areas of concern

- $\quad$ Newsletters that are continually and automatically updated in the form of RSS feeds resourced from Edna. The newsletters relate directly to issues facing beginning teachers.

- Lesson activities and other relevant links are provided under each of the major areas. For example, clicking on the Classroom management link offers resources on student discipline, motivating students and dealing with bullying.

- A weblogging feature provides a space where teachers can 'blog' their first year teaching experiences. The weblog feature enables users to articulate and critically reflect, not only on their own experiences and developing expertise, but also to compare and comment on the experiences of others. The weblogging tool allows users to upload resources such as word documents, pdfs and digital photographs.

\section{c. Supports}

Support within the site can come from both beginning teachers' peers and experienced teacher mentors. The social support provided by other neophytes and teachers who have survived their first year is useful in creating the sense of community that is so lacking for many beginning teachers. This interaction is manifest in a forum titled Keep in touch. Here teachers are asked to 'use the forum to let us know where you are and what you are up to'. The responses are informative and at times unexpected such as this 'cris de coeur':

Just cringing at the thought of going back to school in a weeks time!!! When I remembered the lecture that talked about this web site, and thought I would have a look. I MISS UNI SOOOO MUCH!!!!! I was targeted, got [ ...school], its awful kind of wish I never got targeted...struggling!!! I have a year 5 class, 2 students have ADHD, 1 has Aspergers, 1 ESL. Not to mention endless other issues the students in my class have!!!! Hope to talk to someone I went to uni with, maybe you have had a nightmare 1st term, just like I have. I feel like everything I learnt at uni has gone out the window, I wasn't prepared for this!!!

In relation to the major areas of concern for teachers the site provides mentoring support provided by experienced teachers who have been awarded exemplary teaching awards from the Australian College of Educators (www.austcolled.com.au). A response to a similar concern as the one raised above by another teacher are kept as FAQs for future members to access. For example:

My first appointment was to a year one class and I really understand how overwhelming it can be. Probably the first thing I would suggest is to really focus on establishing routines. It will take some time, but once the children know what they have to do during the literacy 
block or during maths time it makes it easier. It's not as frightening as it seems. I had a great year on K1 a few years ago. How have the classes been organised? Do you have the older K's, younger 1's, independent 1 's?

After starting the day with routines such as weather, attendance etc. I used to head straight into the literacy focus. A big book can be selected with different focuses. eg. phonics for $\mathrm{K}$ and Inverted commas for y1. I followed the literacy session outline (follow url below). Activities are different depending on groups. Before long some groups will actually be mixed (K\&1).

Have one child share their news. In a large newsprint book scribe for $\mathrm{K}$ and have Y1 attempt to write own story. I usually have that child then illustrate the newsbook. This will become your first class made big book and they will all love reading it.

Year one can then write in their journal while $\mathrm{K}$ is introduced to letter of the week. While $\mathrm{K}$ do a phonics activity Y1 can have teacher time on their spelling. If the school does Count me in too maths groups should be easy.

I am happy to help and have countless resources if you need. I'm not sure where you are but I am at [school] if you ever want to drop in after school.

You will be tired but don't worry so are all Kindy or Y1 teachers too.

While drawing on a wealth of experience, the mentor teacher also recognise the benefits of faceto-face meetings where possible. Surprisingly, the proportion of postings to the various categories of issues indicates that the area of Professional responsibilities attracts most requests for support. Many of these are concerns about teachers' relationships with parents, such as, contacting, communicating and working with parents. 
Figure 3: Temporal Sequence for BEST

\begin{tabular}{|c|c|c|c|c|c|}
\hline New Teacher & Lecturer & Mentor & Peer & Manager & Design team \\
\hline & & & & & Designs website \\
\hline & $\begin{array}{l}\text { Makes resource } \\
\text { available }\end{array}$ & & & & \\
\hline \multicolumn{6}{|l|}{$\begin{array}{l}\text { Familiarise } \\
\text { oneself with } \\
\text { resource }\end{array}$} \\
\hline $\begin{array}{l}\text { Posts to the } \\
\text { "Keep in touch" } \\
\text { Forum }\end{array}$ & $\begin{array}{l}\text { Monitors forum } \\
\text { postings }\end{array}$ & & $\begin{array}{l}\text { Responds to } \\
\text { posts }\end{array}$ & $\begin{array}{l}\text { Monitors forum } \\
\text { postings }\end{array}$ & \\
\hline $\begin{array}{l}\text { Accesses } \\
\text { relevant } \\
\text { resources }\end{array}$ & $\begin{array}{l}\text { Monitors } \\
\text { connections to } \\
\text { resources }\end{array}$ & & & $\begin{array}{l}\text { Monitors } \\
\text { connections to } \\
\text { resources }\end{array}$ & \\
\hline $\begin{array}{l}\text { Blogs teaching } \\
\text { experiences }\end{array}$ & Monitors bogs & & $\begin{array}{l}\text { Comments } \\
\text { constructively on } \\
\text { blog }\end{array}$ & Monitors bogs & \\
\hline \multirow{2}{*}{$\begin{array}{l}\text { Posts } \\
\text { issues/concerns } \\
\text { to mentoring } \\
\text { forum }\end{array}$} & $\begin{array}{l}\text { Monitors forum } \\
\text { postings }\end{array}$ & $\begin{array}{l}\text { Provides } \\
\text { guidance }\end{array}$ & $\begin{array}{l}\text { Provides } \\
\text { guidance }\end{array}$ & $\begin{array}{l}\text { Monitors forum } \\
\text { postings }\end{array}$ & \\
\hline & & & & & $\begin{array}{l}\text { Evaluates } \\
\text { community } \\
\text { development and } \\
\text { adjusts design } \\
\text { accordingly }\end{array}$ \\
\hline
\end{tabular}

\section{d. The learning community}

The BEST site has undergone a number of iterations since it was first implemented. The resources are heavily accessed but the levels of communication within forums have been problematic. In its first year of operation, the site had a few 'teething problems'. For example, when the pre-service teachers were oriented to the use of the BEST site prior to the completion of their studies at the university, it was an optional activity at the end of the year, and thus the participation rate was initially quite limited. So awareness of the BEST site was predominantly through emails to beginning teachers at the start of the new school year. University email addresses were gradually removed and students were required to replace them with new addresses. As well as the lack of continuity of email addresses, another reason for reluctance at initial postings to the discussion board involved teachers' names being identifiable in the postings. In subsequent upgrades to the site, the postings now include the option for anonymity. The internet technology itself also caused problems when emails to all members were treated as spam, meaning that emails aimed at motivating teachers to use the site were lost. This problem has also been addressed and rectified. Consequently, in earlier implementations, the participation rate overall has been varied.

We now introduce the BEST site to teachers who are both teaching and studying in their fourth year of a Bachelor of Education. As part of the subject requirements these teachers are asked to 
interact with the BEST site through the social forum and through weblogs. The response to forums has shown a marked increase on earlier implementations. The weblogs that have resulted are used to raise awareness of the significant issues faced by novice teachers and provide an important channel for both beginning and preservice teachers' social construction of school teaching and learning (Herrington, Kervin \& Ilias, 2006).

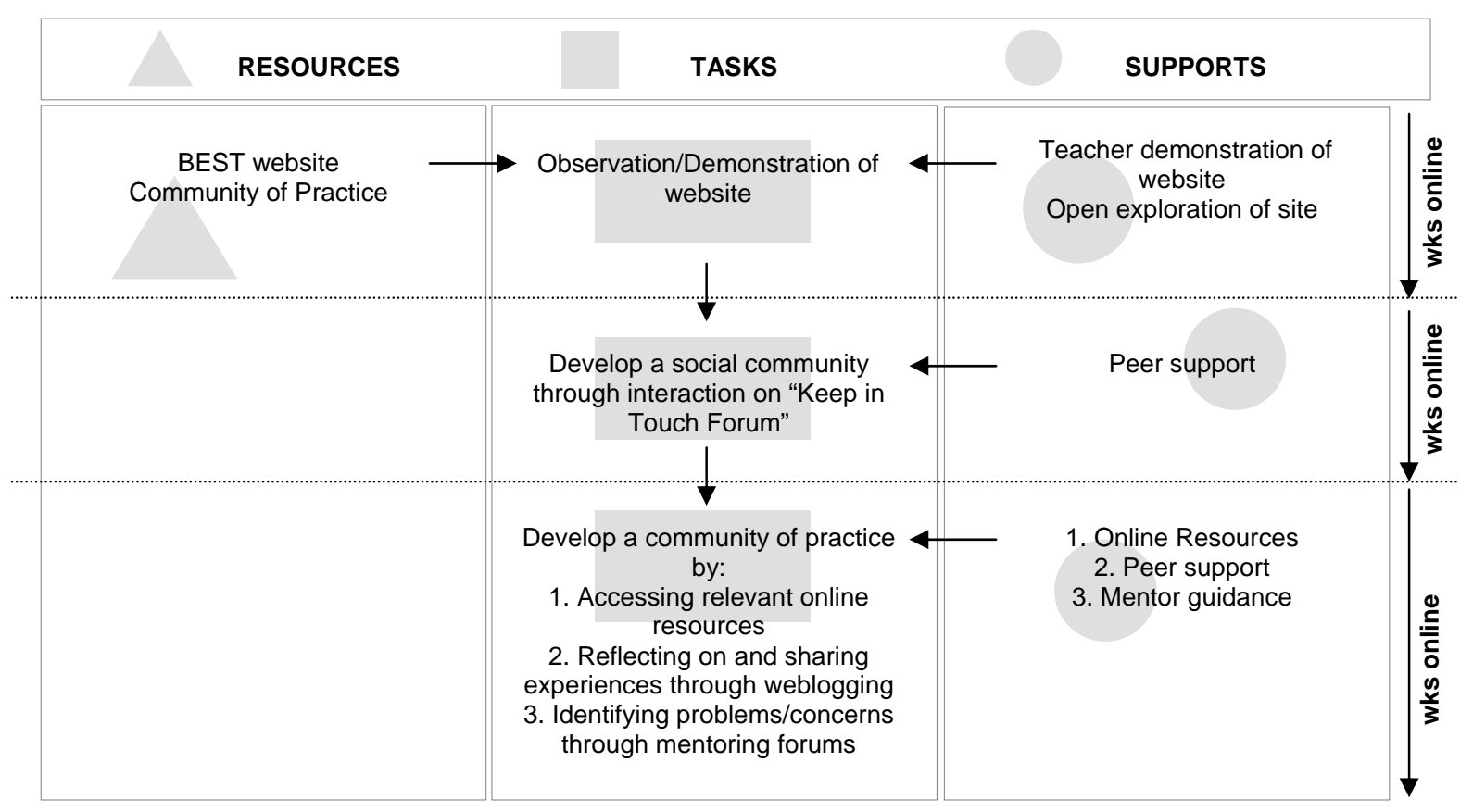

Table 2: Stakeholder representation of BEST

\section{Workplace health \& safety (WHS)}

The Workplace Health and Safety (WHS) course forms a unit of study from a Diploma in Management in the Vocation, Training and education sector. The course was designed to be completed in 10 weeks in a fully online form. Learners in the course are typically all in full time employment and seeking this qualification to improve employment prospects within their own organisations. The course is delivered using WebCT learning management system (LMS) and uses the communications capability of this LMS as the basis of the interaction and communication. The course usually runs with about twenty students, with a balanced gender ratio with students whose ages vary between 20 and 60 . The course is led by an experienced facilitator who keeps the students on-task and to the schedule and provides encouragement, motivation and feedback during the course. Students learn about health and safety in the workplace, policies, procedures, practice and legislative requirements as well as the roles of responsibilities of the various stakeholders in a business in relation to health and safety

\section{a. Tasks}

The WHS course is based around the completion of three tasks which aim to help students to explore the three main areas of workplace health and safety, the regulations, processes and procedures and compliance. Students complete the tasks following a series of directions and guidance and use the available resources to develop their skills, knowledge and understanding of the underpinning information. The students work individually and in groups as a means to provide 
encouragement and facilitation of the learning process. The Web-based tools are used to interact and communicate as well as for information. The tasks have been chosen to represent typical workplace activities that come about from workplace health and safety issues. In order to complete the tasks, students need to develop their knowledge of the processes and procedures and their ability to apply the knowledge and to make meaningful judgements.

Figure 4: Temporal Sequence for Workplace Health and Safety

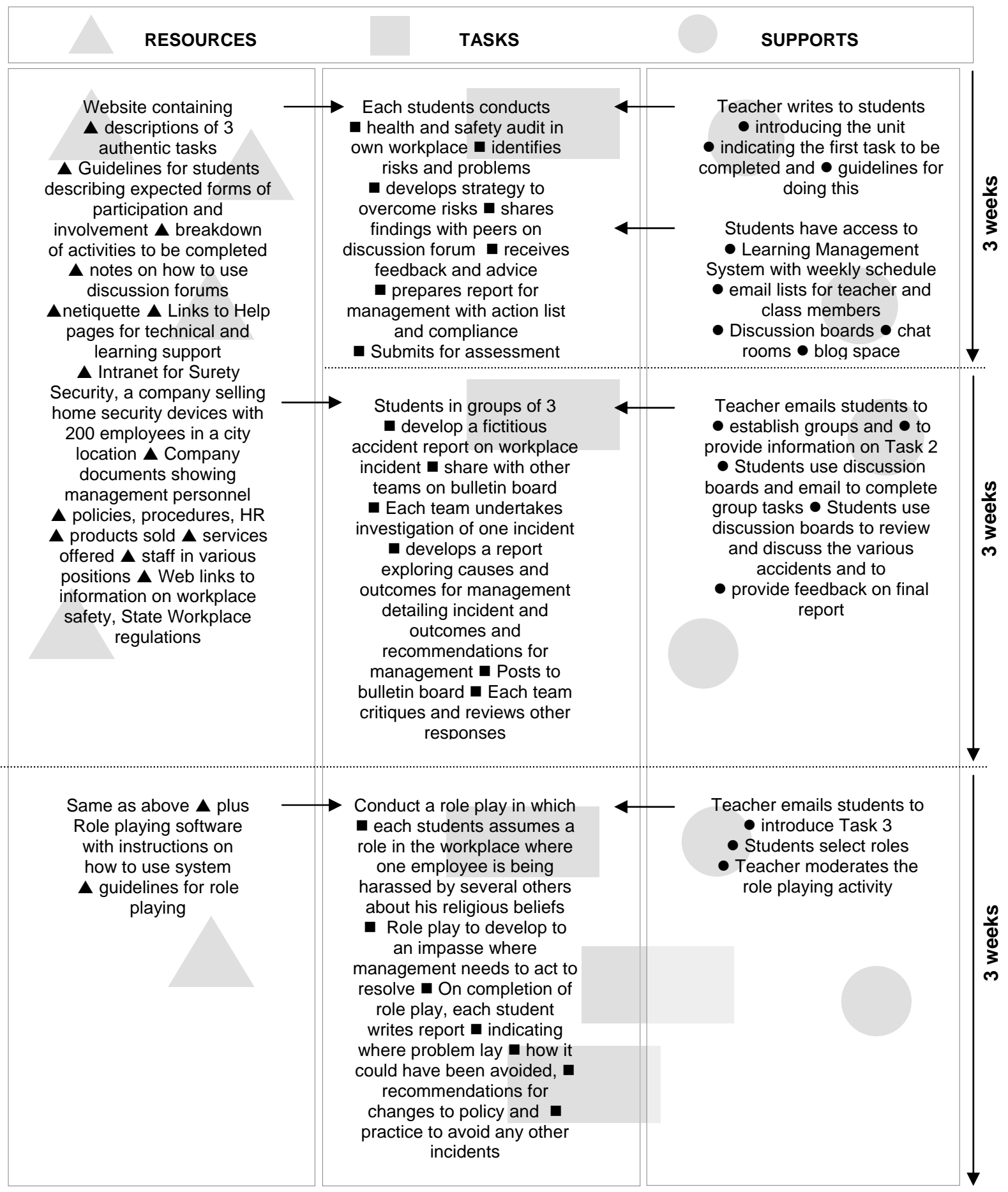




\section{b. Resources}

The course is supported by a range of online learning materials which have been developed through a national grant. The online setting provides access to a fictitious workplace, Surety Security, where the students are cast in the role of workers. Accidents and incidents at the workplace are explored by the students by accessing the company intranet where a large range of relevant and authentic materials are stored mirroring those of an actual business. The site contains links to actual workplace health and safety websites including government and commercial vendors of safety equipment and resources. The course resources also include a role-playing software program which students use in Task 3.

\section{c. Supports}

Within the web site for the course are a range of supporting materials that provide technical and learning information to guide the learners in their learning tasks. The comprehensive online materials are intended to provide the students with access to a range of supports including how to guides and instruction manuals for the various tools. Support for the learning is also provided through the facilitation of a tutor, interaction and communication with other students and a range of collaborative and team-based activities.

\section{d. The learning community}

In participating in the Workplace Health and Safety course, students are required to complete a number of activities with other class members and with members of small groups and teams. The course provides meaningful contexts for the learners to discuss problems and solutions and to learn from the experiences and viewpoints of others. The setting requires students to feel comfortable posting to the boards and comfortable with the advice and feedback they receive. For students who are not able to develop a sense of community, the learning setting will be less effective. The students in the group need to support and assist each other in the conduct of the various tasks and in the reflections that follow as part of the assessment and evaluation. Table 3 provides a set of clear guidelines that show the activities and undertakings of the stakeholders in this learning setting as they complete Task 2 . The learning design indicates who will initiate each action and how it is to be undertaken and completed. Without this information important actions might be missed which could limit the success of the learning setting. When implemented, the strategies described in Figure 4 provide an organisation and support structure that will facilitate and sustain the development of a learning community among learners. 
Table 3: Stakeholder representation of Workplace Health and Safety course

\section{Evaluator}

Facilitator

Student

Coordinator

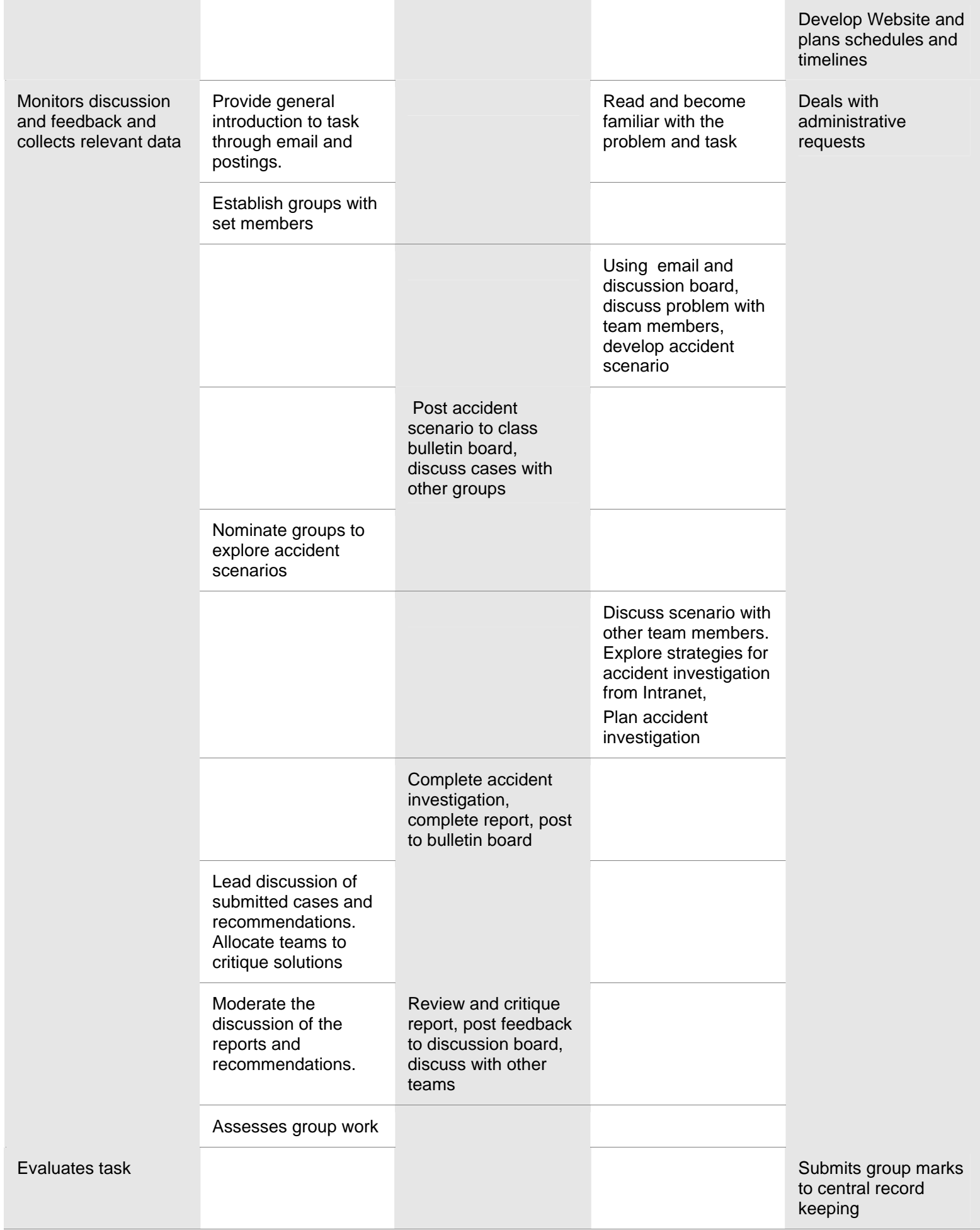




\section{Summary and conclusions}

Authentic learning settings are increasingly being explored by teachers as a means to create meaningful contexts for learning which support higher-order learning and students' abilities to apply learning outcomes in settings beyond the classroom. In many cases the authentic learning settings involve quite complex and detailed learning activities often facilitated through some form of computer and technology application. In such settings, an important component of the learning environment is the presence of some form of collaborative or social learning which often involves the establishing and sustaining of a learning community.

When the learning designs for authentic learning are discussed, the discussion usually entails highlevel descriptions of the general features of the learning settings. The purpose of the representation is usually to provide others with a sense of the general forms of learner and teacher activity so that the scope and nature of the potential learning can be appreciated. Such descriptions and representation of authentic learning designs often provide details of the constituent elements, for example, the learning tasks, resources and supports that are needed in instantiations of the design. In this paper we have provided such high-level representations for three authentic learning settings. In each instance the learning setting involves the establishment of a community among the learners facilitated by a technology application.

The high-level representation of the learning design, while providing an understanding of the scope and nature of the learning may be insufficient for teachers who may wish to implement such a learning design. The representation does not provide adequate detail of the actions, roles and responsibilities of the various stakeholders in order to run the learning design. In this paper we have included a second representation for each learning design in the form of a runnable description. The representation provides a detailed description of those activities required by the various stakeholders in each learning setting that are needed to develop and sustain the learning community. The paper demonstrates clearly that different representation for learning designs can take many forms. To encourage and support reuse of learning designs teachers need access to representations of several types. In this paper we have used two types to illustrate the different functions learning design representations can serve.

Currently there are no common and agreed forms of representation for learning designs. When teachers are asked to describe their teaching approaches, most will use vastly different means. Teachers have difficulty judging what information to provide and how to best provide it. There is still a need for research to explore and discover strategies for representing learning designs to support the sharing and reuse of strong learning designs such as authentic learning. There are currently many forms of learning design representation which can serve many purposes. Research is needed to develop some standard forms that will enable descriptions to be provided in clear and unambiguous ways to assist teachers in accessing and choosing learning designs as well as implementing them in classroom settings.

We would argue that design-based research approaches (Van den Akker, Gravemeijer, McKenney, \& Nieveen, 2006) will be most advantageous for this research agenda. Design-based research requires practitioners and researchers to collaborate in the identification of challenging teaching and learning problems, the creation of prototype solutions based on existing design principles and creativity, and the testing and gradual refinement of both the prototype solutions and the design principles until satisfactory outcomes have been reached by all concerned (Reeves, Herrington, \& Oliver, 2005). Design research approaches promise much greater results than traditional comparative research designs that have most often led to findings of no significant differences (Bernard, Abrami, Lou, Borokhovski, Wade, Wozney, Wallet, Fiset, \& Huang, 2004; Reeves, 2005; Tallent-Runnels, Thomas, Lan, Cooper, Ahern, Shaw, \& Xiaoming, 2006). 


\section{References}

Barab, S. A., Squire, K. D., \& Dueber, W. (2000). A co-evolutionary model for supporting the emergence of authenticity. Educational Technology Research and Development, 48(2), 37-62.

Beetham, H. (2004) Review: developing e-Learning Models for the JISC Practitioner Communities. Retrieved 12 February 2007 from http://www.jisc.ac.uk/uploaded_documents/Review_emodels_draft.doc

Bernard, R. M., Abrami, P. C., Lou, Y., Borokhovski, E., Wade, A., Wozney, L., Wallet, P. A., Fiset, M., \& Huang, B. (2004). How does distance education compare to classroom instruction? A meta-analysis of the empirical literature. Review of Educational Research, 74(3), 379-439.

Blake, K. R. (2000). "Using the World Wide Web to teach news writing online."_Journalism \& Mass Communication Educator 55(1), 4-13.

Bransford, J. D., Vye, N., Kinzer, C., \& Risko, V. (1990). Teaching thinking and content knowledge: Toward an integrated approach. In B. F. Jones \& L. Idol (Eds.), Dimensions of thinking and cognitive instruction (pp. 381-413). Hillsdale, NJ: Lawrence Erlbaum Associates.

Bonk, C., \& Cunningham, D. (1998). Searching for learner-centred constructivist and sociocultural components of collaborative education learning tools. In C. Bonk \& K. King (Eds.), Electronic Collaborators (pp. 25-50). New Jersey: Lawrence Erlbaum.

Brook, C., \& Oliver, R. (2003). Online learning communities: Investigating a design framework. Australian Journal of Educational Technology, 19(2), 139-160.

Brown, J. S., Collins, A., \& Duguid, P. (1989). Situated cognition and the culture of learning. Educational Researcher, 18(1), 32-42.

Brown, J.S., \& Duguid, P. (1993). Stolen knowledge. Educational Technology, 33(3), 10-15.

Chickering, A. W., \& Gamson, Z. F. (1987, March). Seven principles for good practice in undergraduate education. AAHE Bulletin, 39(7), 3-7. Retrieved May 25, 2007, from http://learningcommons.evergreen.edu/pdf/fall1987.pdf

Cognition and Technology Group at Vanderbilt. (1990). Anchored instruction and its relationship to situated cognition. Educational Researcher, 19(6), 2-10.

Dolmans, D., Wolfhagen, H., \& Scherpbier, A. (2003). Development of an instrument to evaluate the effectiveness of teachers in guiding small groups. Higher education, 46(4), 431-446.

Ewing, J., Dowling, J., \& Coutts, N. (1999). Learning using the World Wide Web: A collaborative learning event. Journal of Educational Multimedia and Hypermedia, 8(1), 3-22.

Falconer, I., Beetham, H., Oliver, R., Lockyer. L. \& Littlejohn, A. (2007). Mod4L Final Report: Representing Learning Designs. Accessed 15 May 2007 at http://www.mod4l.com/tikidownload_file.php?fileId=7

Gabriel, M. A. (2004). Learning together: Exploring group interactions online. Journal of Distance Education, 10(1). 54-72.

Goodsell, A., Maher, M., \& Tinto, V., and Associates. (Eds.). (1992). Collaborative learning: A sourcebook for higher education. University Park, PA: National Center on Postsecondary Teaching, Learning, and Assessment.

Gordon, R. (1998). Balancing real-world problems with real-world results. Phi Delta Kappan, 79, 390-393.

Herrington, A. J., Kervin, L. K., \& Ilias, J. (2006). Blogging beginning teaching. In C. Crawford, R. Carlsen, K. McFerrin, J. Price, R. Weber, \& D. Willis (Eds.), Society for Information Technology and Teacher Education Annual International Conference (pp. 2232-2239). Chesapeake, VA: AACE. 
Herrington, J., \& Herrington, A. (1998). Authentic assessment and multimedia: How university students respond to a model of authentic assessment. Higher Education Research and Development, 17(3), 305-322.

Herrington, J., \& Oliver, R. (2000). An instructional design framework for authentic learning environments. Educational Technology Research and Development, 48(3), 23-48.

Herrington, J., Reeves, T. Oliver, R., \& Woo, Y. (2004). Designing authentic activities in webbased courses. Journal of Computing and Higher Education, 16(1), 3-29.

Hiltz, S. R. (1998). Collaborative learning in asynchronous learning environments: building learning Duchastel, P. C. (1997). A Web-based model for university instruction. Journal of Educational Technology Systems, 25(3), 221-228.

Jonassen, D. (2000). Toward a design theory of problem solving. Educational Technology Research and Development, 48(4), 63-85.

Lebow, D., \& Wager, W. W. (1994). Authentic activity as a model for appropriate learning activity: Implications for emerging instructional technologies. Canadian Journal of Educational Communication, 23(3), 231-144.

Liu, X., Magjuka, R. J., Bonk, C. J., \& Lee, S. (2007). Does sense of community matter? An examination of participants' perceptions of building learning communities in online courses. Quarterly Review of Distance Education, 8(1), 9-24.

Lizzio, A., \& Wilson, K. (2005). Self-managed learning groups in higher education: Students' perceptioons of process and outcomes. British Journal of Educational Psychology, 75(3), 373390.

McMillan, D., W. (1996). Sense of Community. The Journal of Community Psychology, 24(4), $315-325$.

McMillan, D., W., \& Chavis, D. M. (1986). Sense of Community: A Definition and Theory. Journal of Community Psychology, 14, 6 - 23.

Oliver, R. \& Harper, B., Hedberg, J., Wills, S., \& Agostinho, S. (2002). Exploring strategies to formalise the description of learning designs. In A. Goody, J. Herrington \& M. Northcote (Eds.), Quality conversations: Research and Development in Higher Education, Volume 25 (pp. 496-504). Jamison, ACT: HERDSA.

Palloff, R.M., \& Pratt, K. (2005). Online learning communities revisited. Presentation to the 21st Annual Conference on Distance Teaching and Learning. Retrieved, 26 October 2006 from http://www.uwex.edu/disted/conference/Resource_library/proceedings/05_1801.pdf

Putnam, R. D. (2000). Bowling Alone. New York: Simon and Schuster.

Roberts, T. S. (Ed.). (2004). Online collaborative learning: Theory and practice. Hershey, PA: Information Science Publishing.

Reeves, T. C. (2005). No significant differences revisited: A historical perspective on the research informing contemporary online learning. In G. Kearsley (Ed.), Online learning: Personal reflections on the transformation of education (pp. 299-308) Englewood Cliffs, NJ: Educational Technology Publications.

Reeves, T. C., Herrington, J., \& Oliver, R. (2005). Design research: A socially responsible approach to instructional technology research in higher education. Journal of Computing in Higher Education, 16(2), 97-116.

Schuck, S. (2003). Getting help from the outside: developing a support network for beginning teachers. Journal of Educational Enquiry. 4(1), 49-67.

Slavin, R. (1990). Cooperative learning: Theory, research and practice. Hillsdale, NJ: Prentice Hall. 
Slavin, R.E., Hurley, E.A., \& Chamberlain, A.M. (2003). Cooperative learning and achievement: Theory and research. In W.M. Reynolds \& G.E. Miller (Eds.), Handbook of Psychology, Volume 7 (pp. 177-198). Hoboken, NJ: Wiley.

Swan, K., \& Shea, P. (2005). The development of virtual learning communities. In. S. R. Hiltz \& R. Goldman, Asynchronous Learning Networks: The Research Frontier (pp. 239-260). New York: Hampton Press.

Tallent-Runnels, M. K., Thomas, J. A., Lan, W. Y., Cooper, S., Ahern, T. C., Shaw, S. M., \& Xiaoming, L. (2006). Teaching courses online: A review of the research. Review of Educational Research, 76(1), 93-135.

Van den Akker, J., Gravemeijer, K., McKenney, S., \& Nieveen, N. (2006) Educational design research. London: Routledge.

Vygotsky, L. S. (1978). Mind in society: The development of higher psychological processes (M. Cole, V. John-Steiner, S. Scribner \& E. Souberman, Trans.). Cambridge: MA: Harvard University Press.

Wubbels, T., \& Levy, J. (eds.) (1993). Do You Know What You Look Like? Interpersonal Relationships In Education. Washington D.C.: The Falmer Press.

Yazici, H. (2005). A study of collaborative learning style and team learning. Education and Training, 47(3), 216-229.

Young, M. F. (1993). Instructional design for situated learning. Educational Technology Research and Development, 41(1), 43-58.

Zhang, J., \& Walls, R. T. (2006). Instructors’ self-perceived pedagogical principle implementation in the online environment. Quarterly Review of Distance Education, 7(4), 413-426.

Copyright @ 2007 Ron Oliver, Jan Herrington, Anthony Herrington, Thomas Reeves 